\title{
Egg production in the euryhaline tilapia, Sarotherodon melanotheron heudelotii, experimentally maintained in fresh, sea and hypersaline waters
}

\author{
Rémi Dugué ${ }^{1, a}$, Etienne BARAs ${ }^{2}$, Moussa GueYE ${ }^{3}$, Jean-Christophe Avarre ${ }^{2}$, Yan CoMbes ${ }^{1}$, \\ Christophe COCHET ${ }^{1}$ and Marc LEGENDRE ${ }^{2}$ \\ 1 IRD, UMR 226 ISE-M, c/o IRSTEA, BP 5095, 34196 Montpellier Cedex 05, France \\ 2 IRD, UMR 226 ISE-M, Université Montpellier 2, 34095 Montpellier Cedex 05, France \\ 3 IRD, route des Hydrocarbures, BP 1386, 18524 Dakar, Senegal
}

Received 30 September 2014; Accepted 21 November 2014

\begin{abstract}
Through the experiments presented here we wanted to test whether egg production of the black-chinned tilapia Sarotherodon melanotheron heudelotii under experimental conditions varies as a function of ambient salinity (fresh waters $v s$. sea waters $v s$. hypersaline waters, 0,35 and 70, respectively) and whether these responses differ between fish acclimated within a few weeks from fresh water to saline and hypersaline environments (experiments E1 and E2, monitoring over 10 and 18 weeks), and individuals born and raised all life long at the experimental salinities (E3, monitoring over 18 weeks). In total, 233 spawns were collected. In each of the three experiments, the reproductive investment (gram of egg per gram of female over 2 weeks) did not differ between salinities of 0 and 35, whereas it was 2-3 times lower at 70 than at 0-35, because of lower spawning frequency (E1-E3), smaller clutch size (E1) and lower spawn mass (E1-E3). Finally, fish acclimated to salinity from fresh water over a few weeks and those maintained at a particular salinity all life long showed similar reproductive traits, thereby emphasizing the remarkable physiological plasticity of this species.
\end{abstract}

Keywords: Fish acclimation / Adaptation / Reproduction / Salinity / Mouthbrooding tilapia / Cichlid

\section{Introduction}

Few species of teleosts have been reported to occur in strongly hypersaline waters ( $>70$; Simier et al. 2004; Whitfield et al. 2006), and even fewer species are known to reproduce successfully in these conditions. Among these are several killifishes [the California killifish Fundulus parvipinnis (Girard 1854), Rao 1975; the sheepshead minnow Cyprinodon variegatus variegatus (Lacepède 1803), Nordlie et al. 1991; the Arabian killifish Aphanius dispar dispar (Rüppell 1829), Plaut 2000], the milkfish Chanos chanos [(Forsskål 1775); Crear 1980] and two cichlids [the Mozambique tilapia Oreochromis mossambicus (Peters 1852); Chervinsky 1982; the black-chinned tilapia Sarotherodon melanotheron (Rüppel 1852); Albaret 1987].

In the Sine Saloum Estuary (Senegal), which regularly experiences episodes of severe drought, water salinity rises with increasing distance to the sea as a result of strong evaporation, and salinities over 130 can be observed in some places located up to $100 \mathrm{~km}$ from the sea. Several species of this ecosystem, which are viewed as part of the "resistance community" in case of drought (Albaret 1987) have

\footnotetext{
a Corresponding author: remi.dugue@ird.fr
}

evolved ways of surviving and reproducing at very high salinity. They include a Clupeidae, the bonga shad Ethmalosa fimbriata (Bowdich 1825), a Mugilidae, the sicklefin mullet Liza falcipinnis (Valenciennes 1836), a Gerreidae, the striped mojarra Gerres nigri (Günther 1859) and a Cichlidae, the black-chinned tilapia Sarotherodon melanotheron heudelotii (Duméril 1859), Panfili et al. (2006). The latter species has adapted remarkably well to a wide range of salinity, as it has been found to reproduce at salinities as high as 110 , but can also spawn in marine, brackish and fresh waters (Albaret 1987; Panfili et al. 2004; Guèye et al. 2012). Such capacities are just exceptional in cichlids (Keenleyside 1991). By comparison, there is some evidence that $O$. niloticus can survive to salinities as high as 70, but its growth and reproductive capacities are strongly impaired at salinities higher than 20 (Schofield et al. 2011; Fridman et al. 2012). Likewise, Watanabe et al. (1989) found that the reproductive performance of the Florida red tilapia declined sharply at salinities higher than 18 . Several species of cichlids living in endorheic lakes of the Rift Valley that belong to the "evaporation type" are also capable to live and reproduce in extreme conditions, especially in terms of high alkalinity e.g., Oreochromis amphimelas Hilgendorf 1905 
in Lake Manyara; Alcolapia alcalica Hilgendorf 1905 in Lake Natron; Alcolapia grahami (Boulenger 1912) in Lake Magadi (Lévêque 1999; Wood et al. 2002, 2012; Papah et al. 2013). Yet in terms of salinity, none of these lakes exceeds 55-60 at any time of the year.

Because of its exceptional capacities, S. m. heudelotii is considered as an interesting model for studying the physiological adaptation to salinity (Akinrotimi et al. 2007; Tine et al. 2008, 2010; Ouattara et al. 2009; Lorin-Nebel et al. 2012; Riou et al. 2012; Avarre et al. 2014). It is also a good candidate for aquaculture in African lagoons and was the subject of several studies on an integrated fish-plankton aquaculture system in brackish water (Gilles et al. 2008, 2013)

Studies on wild populations of $S$. m. heudelotii indicate that fish in hypersaline environments attain sexual maturity at a much smaller body size, they produce smaller eggs but their relative fecundity is higher than in other environments (Panfili et al. 2004, 2006; Guèye et al. 2012). Similar trends have been observed in fishes living in adverse environmental conditions, as regards salinity, oxygen, food availability or predation pressure, and are interpreted as trade-offs in the context of life history strategies (mosquitofish Gambusia spp., Brown-Peterson and Peterson 1990; Alcaraz and García-Berthou 2007; Caspian roach Rutilus rutilus caspicus, Naddafi et al. 2005; for cichlids: Reardon and Chapman 2008, 2012; Russell et al. 2012). Populations of $S$. m. heudelotii exhibit a marked genetic structure (Ndiaye 2012) and studies of their mobility indicate that this species is rather sedentary (Diouf et al. 2006). Henceforth, it is uncertain whether the aforementioned variations in the life history traits of $S$. $m$. heudelotii in environments with contrasting salinities reflect genetic differences between populations or phenotypic plasticity in response to salinity or to associated environmental factors (food, predation, oxygen). Moreover the actual variations of the reproductive investment of this species over a broad salinity range remain to be determined, because some key parameters such as the spawning frequency or the actual number of eggs per spawn can hardly be determined in field conditions. So far, there has been a single experimental study on the effect of salinity on the reproduction of $S . m$. heudelotii acclimated to 0 and 35 (Gilles et al. 2004), but no information is available for hypersaline waters.

The present study aimed at comparing in experimental environments the reproductive traits (spawning frequency, clutch size (i.e. number of eggs in a spawn), egg mass and dry matter content) of $S . m$. heudelotii from the same strain, cultivated in fresh water and acclimated to different salinities $(0,35,70)$. As no information is available on the incidence of the dynamics of acclimation to saline and hypersaline waters on the reproduction of $S$. m. heudelotii, it was further tested whether reproductive performance varied between fish acclimated to the different salinities over a few weeks, and individuals born and raised at the same salinity throughout. On the basis of existing information of fish responses to ambient salinity, it could be expected that a) the reproductive investment of female fish is lower in hypersaline waters than at lower salinities, as the former environment is more energy-demanding (e.g. Gardell et al. 2013), and that b) fish born in hypersaline waters would be less affected than those acclimated rapidly to this particular salinity.

\section{Materials and methods}

\subsection{Fish and experimental design}

Fish originated from a Senegalese population of $S . m$. heudelotii, Niayes (natural ponds) of Dakar (Senegal) and were transferred to our experimental facilities (Montpellier) 15 years ago. Since then they were bred in fresh water exclusively. In order to minimize the loss of genetic diversity, 3-10 mate pairs were used to obtain a new generation, and generation time was about 18 months. It has been experimentally demonstrated that $S$. m. heudelotii born in fresh water could acclimate to a broad range of salinities (0-90; Ouattara et al. 2009). By contrast, it was unknown whether fish acclimated to hypersaline conditions could successfully reproduce. In order to verify that fish could reproduce at 70 after a short period of acclimation, a preliminary experiment (E1) was realized. Fish (2-3 years old) were acclimated from 0 to 70, then their reproductive characteristics (spawning frequency, clutch size, egg size and dry matter content) were studied over the next 10 weeks, and compared to those of fish maintained in fresh water or acclimated to marine water (experiment E1). Based on the outcome of this preliminary experiment (see results), a full experiment (E2) using 2-3-year old fish maintained in fresh water or acclimated at 35 or 70 was conducted, with some methodological adjustments (food type, water temperature, duration of experiment; see below). In E2 fish reproduction was monitored over a longer period (18 weeks), starting 5 weeks after the target salinity was attained. At every experimental salinity offspring from E2 broodfish were collected (about 50 fry, from 6 to 8 progenies) and raised in an independent recirculating water system at the same salinity since hatching. These three pools served for a third experiment (E3), which started when fish were 9-11 months old, about 3 months after they became sexually mature. The experimental protocol and duration of fish monitoring during E3 were identical to those of E2, except there was no need for an acclimation period and that broodfish in E3 (females $=121 \pm 27 \mathrm{~g}$, males $154 \pm 37 \mathrm{~g}$ ) were smaller than in experiments E1 (females = $262 \pm 24 \mathrm{~g}$, males $318 \pm 65 \mathrm{~g}$ ) and E2 (females $=276 \pm 38 \mathrm{~g}$, males $286 \pm 31 \mathrm{~g}$ ).

\subsection{Rearing conditions}

In all three experiments, fish were studied in three indoor recirculating water systems (one for each experimental salinity), each of them comprising two breeding tanks $(2.5 \mathrm{~m} \times$ $0.53 \mathrm{~m} \times 0.30 \mathrm{~m}$ depth) and one pair of interconnected mechanical and biological filters. Breeding tanks were provided with shelters consisting of 100-mm PVC cylinders of various lengths. Each tank hosted 10 (E1) or 12 mature fish (E2, E3), with a 1:1 sex ratio that was found optimal for egg production in captive groups of $S$. melanotheron (Legendre and Trébaol 1996). In each experimental situation, males were never smaller than females in order to ensure that mouthbrooding capacity was not limiting (Aronson 1949; Legendre and Ecoutin 1989; Legendre and Trébaol 1996). Photoperiod was $12 \mathrm{~L}: 12 \mathrm{D}$, water temperature was regulated $\left(26-27^{\circ} \mathrm{C}\right.$ during E1; 28-29 ${ }^{\circ} \mathrm{C}$ during E2 and E3) with a Biotherm thermostat connected to $300-\mathrm{W}$ submersed heaters and oxygen was 
maintained near saturation by air pump. Fish were fed with commercial pellets that were distributed by hand during the morning in a single daily meal to minimize disturbance. The feeding level was set at $0.5 \%$ of fish biomass per day. During E1, sinking pellets were used (Biomar, crude proteins: 41\%; lipids: 20\%). During E2 and E3, it was preferred using floating pellets (LeGouessan, crude proteins: 32\%; lipids: 9\%), which were easier to remove from the tanks for preserving water quality in case the meal was not fully ingested.

In each experiment, fish were transferred to experimental tanks on the same day. During E3, experimental salinities were maintained at the target values throughout. During E1 and E2, salinity was progressively increased from 0 to 35 or 70 by the progressive addition of synthetic sea salt ("Instant Ocean", Aquarium system, Sarrebourg, France), at a rate of about $1 \mathrm{~g}$ of salt day ${ }^{-1}$, so that bacteria in the biological filters and fish could acclimate progressively. The increase of salinity for salinity 35 started about one month later than for salinity 70 in order that the targeted experimental salinities were attained at the same time. In the three experiments, water salinity was measured with a refractometer (every day during the acclimation period and every two days thereafter) and adjusted accordingly by addition of either synthetic sea salt or fresh water. The levels of $\mathrm{NO}_{2}^{-}$and $\mathrm{NH}_{4}^{+}$ions were measured weekly (Hanna Instrument, RI, USA) to assess the efficiency of the biological filters. On a few occasions during the acclimation period of $\mathrm{E} 1$, the levels of $\mathrm{NO}_{2}^{-}$and $\mathrm{NH}_{4}^{+}$at salinity $>35$ exceeded $1 \mathrm{ppm}$, and about $25 \%$ of the water was changed to restore water quality. As a consequence, larger bio-filters (160 vs. $40 \mathrm{~L})$ were used during E2 and E3, which allowed the maintenance of a good water quality throughout.

During the preliminary experiment (E1), fish that died during the acclimation and monitoring periods were not replaced, as no other fish undergoing acclimation to salinity were available. During the other two experiments, dead fish were replaced in order to maintain stable sex ratio and fish density, using fish having undergone similar dynamics of acclimation to salinity (E2) or fish from the same cohort born at the target salinity (E3).

\subsection{Fish monitoring}

To minimize the disturbance of experimental fish, the monitoring took place every 7 days. In $S$. melanotheron, mouthbrooding is normally performed by the male parent only (Trewavas 1983), but females can occasionally pick up some eggs or a spawn when the sex ratio is in favor of females (Legendre and Trébaol 1996) or when all present males are already mouthbrooding (Aronson 1949). Henceforth, upon weekly checks, all fish (males and females) were examined for mouthbrooding activity, and the gender of the incubating parent was noted. Fish were gently captured one by one with a hand net and placed in a bucket filled with water at the dedicated salinity. Their lower jaw was carefully depressed manually; mouthbrooded eggs sank in the bucket and were collected.

The entire set of collected eggs was first photographed for determining clutch size (using ImageJ freeware; Abramoff et al. 2004). A sample of 100 eggs was weighed (nearest $0.1 \mathrm{mg}$ ) for determining the mean wet mass (WM) of eggs, then heated overnight at $105{ }^{\circ} \mathrm{C}$ for determining their water content and dry mass (DM). Another sample of eggs was examined under the stereo-microscope for determining the developmental stage, because the WM and water content of developing eggs may vary during ontogeny. Eggs were assigned to one of the four following categories, corresponding to different ages (days after fertilization, daf): (1) young embryos with no pigmentation ( $<3 \mathrm{daf})$, (2) presence of melanocytes, but no pigmentation of the eye (3-4 daf), (3) "eyed" stage, with retinal pigmentation (4-5 daf) and (4) ready to hatch (6-7 daf; modified from Shaw and Aronson 1954, after calibration with spawns of $S$. m. heudelotii incubated in McDonald incubators at $27^{\circ} \mathrm{C}$ ).

\subsection{Calculations and statistics}

In the three experiments, the spawning frequency at a particular salinity was calculated as the ratio between the number of clutches collected during a particular period of time and the number of fish pairs, in order to take into account possible discrepancies between mortality rates at different salinities or between experimental conditions. At all salinities, it was observed that the number of collected progenies varied substantially between consecutive weeks, as many spawning events were seemingly synchronized, thereby limiting the number of fish ready to spawn on the next week. To buffer this oscillation, the spawning frequency was hence analyzed on a 2-week basis. The reproductive effort per spawning was estimated from the mean WM of spawns (clutch size $\times$ average WM of eggs; Legendre and Ecoutin 1989), which was expressed by reference to the average WM of females to take into account discrepancies between the size of fish between experimental situations. The total reproductive investment (egg production per period of 2 weeks, \% of female WM) in every experimental situation was calculated by equating the egg production over 2 weeks (spawning frequency $\times$ clutch size $\times$ egg mass, in terms of WM or DM) to the body weight of females.

The proportions of spawns at different developmental stages in each experimental situation (salinity $\times$ experiment) were compared with contingency table analyses. One-way analysis of variance (ANOVA) was used to compare the WM and DM proportion of eggs at different developmental stages. Data from E1 and E2-E3 were analysed separately, because of different experimental conditions of fish maintenance. Data (spawning frequency, clutch size, egg WM, DM proportion, total WM and DM of spawns, and total reproductive investment, in terms of WM and DM) collected at different salinities were compared with one-way (E1) or 2-way ANOVA (E2-E3) and Scheffe F-tests for post hoc comparisons. Null hypotheses were rejected at $p<0.05$.

\section{Results}

In total, 233 spawns were collected during the three experiments and all of them were mouthbrooded by males exclusively. In each spawn, all eggs were at the same developmental stage. There were progenies at all developmental stages, except at salinity 70 in E2 and E3 (Table 1), where none had 
Table 1. Variation of the numbers of eggs in a spawn (mean \pm SD) in $S$. m. heudelotii during three experiments (E1-E3) as a function of ambient salinity $(0,35$ or 70$)$ and egg developmental stage (1-4; "young" refers to all stages before the apparition of pigments) and $n$ is the total number of spawns collected during the experiments (10 weeks for E1, 18 weeks for E2 and E3). Within a particular line, values that share a lowercase letter in common do not differ at $p<0.05$ (Scheffe post-hoc tests). No statistics for E1 at salinity 70 because of the small amount of spawns $(n=6), p$-values that are indicated as ${ }^{* *},{ }^{*}$ and NS stand for $p<0.01, p<0.05$ and $p \geq 0.05$, respectively.

\begin{tabular}{|c|c|c|c|c|c|c|c|c|}
\hline \multirow{2}{*}{\multicolumn{2}{|c|}{$\begin{array}{l}\text { Experiment } \\
\text { and salinity }\end{array}$}} & \multirow[b]{2}{*}{$n$} & \multicolumn{4}{|c|}{ Egg developmental stage } & \multirow[b]{2}{*}{$F$} & \multirow[b]{2}{*}{$p$} \\
\hline & & & 1. "Young" & 2. Melanocyte & 3. Eyed & 4. Ready to hatch & & \\
\hline \multirow{3}{*}{ E1 } & 0 & 24 & $618 \pm 148 \mathrm{a}$ & $639 \pm 67 a$ & $488 \pm 165 b$ & $474 \pm 215 b$ & 4.13 & * \\
\hline & 35 & 25 & $698 \pm 188 \mathrm{a}$ & $524 \pm 156 a$ & $589 \pm 201 \mathrm{a}$ & $748 \pm 203 a$ & 1.26 & NS \\
\hline & 70 & 6 & 434 & - & $348 \pm 171$ & $283 \pm 288$ & & - \\
\hline \multirow{3}{*}{ E2 } & 0 & 30 & $482 \pm 181 \mathrm{a}$ & $439 \pm 202 \mathrm{a}$ & $375 \pm 150 a b$ & $235 \pm 120 \mathrm{~b}$ & 3.73 & * \\
\hline & 35 & 35 & $471 \pm 209 a$ & $420 \pm 175 a$ & $283 \pm 101 \mathrm{~b}$ & $219 \pm 125 b$ & 5.21 & ** \\
\hline & 70 & 17 & $345 \pm 102 \mathrm{a}$ & $452 \pm 61 \mathrm{a}$ & - & - & 2.46 & NS \\
\hline \multirow{3}{*}{ E3 } & 0 & 34 & $333 \pm 122 a$ & $312 \pm 69 \mathrm{a}$ & $226 \pm 15 b$ & $217 \pm 100 b$ & 3.69 & * \\
\hline & 35 & 38 & $471 \pm 162 \mathrm{a}$ & $379 \pm 106 \mathrm{ab}$ & $297 \pm 117 b c$ & $246 \pm 122 c$ & 5.46 & $* *$ \\
\hline & 70 & 23 & $283 \pm 129 a$ & $322 \pm 166 \mathrm{a}$ & - & - & 0.35 & NS \\
\hline
\end{tabular}

Table 2. Spawning frequency, characteristics of spawns and reproductive investment of $S$. $m$. heudelotii during experiment E1 (10 weeks). Values are means $\pm \mathrm{SD}$, F: female; M: male. Within a particular line, values that do not share a lowercase letter in common differ at $p<0.05$ (Scheffe post-hoc tests). Within each cell, the $F$-value and the $p$-value are given; $p$-values that are indicated as ${ }^{* *},{ }^{*}$ and NS stand for $p<0.01$, $p<0.05$ and $p \geq 0.05$, respectively.

\begin{tabular}{lcccccc}
\hline \multirow{2}{*}{ Variable } & \multicolumn{4}{c}{ Salinity } & \multicolumn{3}{c}{ Statistics } \\
\cline { 2 - 7 } & 0 & 35 & 70 & $F$ & $p$ & $d f$ \\
\hline broodfish & & & & & \\
$\quad$ at the end of acclimation period & $9 \mathrm{M} / 8 \mathrm{~F}$ & $8 \mathrm{M} / 7 \mathrm{~F}$ & $8 \mathrm{M} / 5 \mathrm{~F}$ & - & - & - \\
$\quad$ at the end of monitoring period & $9 \mathrm{M} / 8 \mathrm{~F}$ & $7 \mathrm{M} / 7 \mathrm{~F}$ & $8 \mathrm{M} / 3 \mathrm{~F}$ & - & - & - \\
Number of spawns & 24 & 25 & 6 & - & - & - \\
Spawns per female over 2 weeks & $0.60 \pm 0.19 \mathrm{a}$ & $0.71 \pm 0.20 \mathrm{a}$ & $0.35 \pm 0.11 \mathrm{~b}$ & 3.96 & $*$ & 14 \\
Number of eggs in a spawn & $630 \pm 184 \mathrm{a}$ & $623 \pm 237 \mathrm{a}$ & $413 \pm 156 \mathrm{~b}$ & 4.88 & $*$ & 54 \\
Egg WM (mg) & $16.6 \pm 2.2 \mathrm{a}$ & $15.7 \pm 2.4 \mathrm{a}$ & $14.6 \pm 2.9 \mathrm{a}$ & 1.66 & $\mathrm{NS}$ & 54 \\
Egg DM (proportion of WM) & $0.40 \pm 0.02 \mathrm{a}$ & $0.40 \pm 0.03 \mathrm{a}$ & $0.39 \pm 0.05 \mathrm{a}$ & 0.98 & $\mathrm{NS}$ & 54 \\
Spawn WM (\% female WM) & $3.71 \pm 1.07 \mathrm{a}$ & $3.63 \pm 1.02 \mathrm{a}$ & $2.14 \pm 1.41 \mathrm{~b}$ & 4.17 & $*$ & 54 \\
Spawn DM (\% female WM) & $1.50 \pm 0.44 \mathrm{a}$ & $1.45 \pm 0.40 \mathrm{a}$ & $0.80 \pm 0.54 \mathrm{~b}$ & 5.17 & $* *$ & 54 \\
Reproductive investment over 2 weeks & & & & & \\
$\quad$ WM (\% female WM) & $2.23 \pm 0.60 \mathrm{a}$ & $2.47 \pm 0.93 \mathrm{a}$ & $0.72 \pm 0.40 \mathrm{~b}$ & 11.08 & $* *$ & 14 \\
DM (\% female WM) & $0.90 \pm 0.24 \mathrm{a}$ & $1.03 \pm 0.41 \mathrm{a}$ & $0.29 \pm 0.18 \mathrm{~b}$ & 10.99 & $* *$ & 14 \\
\hline
\end{tabular}

attained the stage of retinal pigmentation, thereby implying that these spawns were laid less than 5 days before collection. The mean egg WM and DM content did not differ significantly between egg developmental stages, in any of the nine experimental situations (one-way ANOVA, $p>0.05$ ). Therefore, comparisons between experiments and salinities for these two variables were done irrespectively of the developmental stage of eggs.

Clutch size (number of eggs in a spawn) never varied significantly between progenies with eggs at developmental stages 1 and 2 in any of the nine experimental situations (Table 1). By contrast, in several situations, clutch size decreased significantly in progenies with older embryos (stages 3 and 4; Table 1), which might reflect egg mortality or loss during mouthbrooding. In order to compensate for a potential bias when comparing experimental situations with different proportions of progenies at different developmental stages, clutch sizes at stages 3 and 4 were back-estimated as follows: $E C_{i}=O C_{i} \times O C_{m 1-2} / O C_{m i}$, where $E C_{i}$ and $O C_{i}$ are the estimated and observed clutch size of a particular spawn at stage $i$ (3 or 4), and $O C_{m 1-2}$ and $O C_{m i}$ are the mean observed clutch sizes at stages 1 and 2 and $i$, respectively. Calculations of spawn mass (WM or DM) and reproductive investment (WM or DM) and associated statistics shown hereafter were done using back-estimated values of clutch sizes (Tables 2 and 3; Fig. 1). Results with non-corrected data are given in Table 4.

\subsection{Experiment E1}

In total, 55 progenies were collected during E1, of which only six at salinity 70 . This was partly due to the higher mortality of broodfish at salinity 70 in comparison to lower salinities (dead fish were not replaced during this experiment, Table 2), seemingly due to the higher aggressiveness of fish in these groups. The reproductive performance of fish at salinities 0 and 35 did not differ significantly in terms of spawning frequency, clutch size and egg WM and DM. Fish at salinity 70 produced slightly smaller eggs than fish at the other two experimental salinities, but this trend was not significant. By contrast, they spawned about twice less frequently and on average their spawns contained significantly fewer $(<450)$ eggs than those produced at salinities 0 and 35 (> 600 eggs on average; 
Table 3. Statistics (two-way ANOVA) of the results during experiments E2 and E3 (illustrated in Fig. 1). WM is the wet mass and DM is the dry mass. Within each cell, the $F$-value and the $p$-value are given; $p$-values that are indicated as ${ }^{* * *},{ }^{* *},{ }^{*}$ and NS stand for $p<0.001, p<0.01$, $p<0.05$ and $p \geq 0.05$, respectively.

\begin{tabular}{lcccc}
\hline Variable & Salinity & Experiment & Interaction & $d f$ \\
\hline Spawns per female over 2 weeks & $4.55^{*}$ & $0.01 \mathrm{NS}$ & $0.37 \mathrm{NS}$ & 53 \\
Number of eggs in a spawn & $3.47 \mathrm{NS}$ & $7.20^{* *}$ & $2.65 \mathrm{NS}$ & 176 \\
Egg WM (mg) & $0.58 \mathrm{NS}$ & $198.8^{* * *}$ & $10.69^{* * *}$ & 176 \\
Egg DM (proportion of WM) & $1.67 \mathrm{NS}$ & $6.89^{* * *}$ & $1.36 \mathrm{NS}$ & 176 \\
Spawn WM (\% female WM) & $3.93^{*}$ & $0.83 \mathrm{NS}$ & $1.03 \mathrm{NS}$ & 176 \\
Spawn DM (\% female WM) & $3.56^{*}$ & $0.13 \mathrm{NS}$ & $0.65 \mathrm{NS}$ & 176 \\
Reproductive investment over 2 weeks & & & & \\
$\quad$ WM (\% female WM) & $7.67^{* *}$ & $0.66 \mathrm{NS}$ & $1.35 \mathrm{NS}$ & 53 \\
DM (\% female WM) & $7.70^{* *}$ & $0.21 \mathrm{NS}$ & $0.99 \mathrm{NS}$ & 53 \\
\hline
\end{tabular}

Table 2). These differences concurred to make the reproductive investment at salinity 70 about 3 times lower than in fresh or marine waters.

\subsection{Experiments E2 and E3}

In total, 82 spawns were collected during E2 (30, 35 and 17 at salinities of 0,35 and 70, respectively) and 96 during E3 (35, 38 and 23, respectively). The results are illustrated in Figure 1 and corresponding statistics (two-way ANOVA) are given in Table 3. The average mortality rates of males and females were similar $\left(0.15\right.$ vs. $0.13 \%$ day $\left.^{-1}\right)$. There was no consistent effect of salinity on mortality either. During E3, mortality in fresh water averaged $0.47 \% \mathrm{day}^{-1}$ and was much higher than at other salinities $\left(0.02\right.$ and $0 \% \mathrm{day}^{-1}$, at salinities 35 and 70 , respectively), in contrast to the situations during E2 (and also E1), where mortality in fresh water was almost null. As during E1, most deceased fish exhibited traces of blows on their mouth or flanks, thereby suggesting that they died following agonistic interactions.

The spawning frequency did not differ between experiments, but it varied significantly between salinities (Fig. 1a): on average the spawning frequency in hypersaline waters was less than $60 \%$ of those in fresh and marine waters, which averaged about one spawn per female every 6 weeks. Clutch size did not differ between salinities, but was on average smaller during E3 than during E2 (Fig. 1b). Egg WM and DM proportion differed significantly between E2 and E3. During E2, these characteristics did not vary as a function of ambient salinity, whereas during E3, the eggs produced in fresh water had a higher WM but lower water content than those in marine and hypersaline waters (Figs. 1c and 1d).

Larger clutch size and higher egg mass concurred to make the average WM of spawns during E2 much higher than during E3 ( $>6.7 \mathrm{~g} v s .<4.2 \mathrm{~g})$. This variation largely owed to the difference between the WM of broodfish in E2 and E3 (see methods). Indeed, when the masses (WM and DM) of spawns were equated to the WM of females, no significant differences were found between experiments (Table 3). By contrast, the spawn mass in hypersaline waters was significantly lower than in marine waters, both for WM and DM (Figs. 1e and 1f). The total reproductive investment in hypersaline waters was about twice lower than in fresh and marine waters (Figs. 1g and 1h).
Analyses of the data with non-corrected values of clutch size gave similar conclusions, except for spawn mass (WM and DM), which did not vary significantly between salinities (see Table 4).

\section{Discussion}

The present study was the first attempt to characterize the egg production of $S$. $m$. heudelotii in experimental conditions at water salinities ranging from fresh to hypersaline waters. It provided evidence that fish from a freshwater strain can successfully reproduce at salinities of 0,35 and 70 , regardless the duration of the acclimation period, from a few weeks to entire life. In each of the three experiments carried out, the reproductive investment did not differ between salinities of 0 and 35, whereas at a salinity of 70 , it was systematically 2-3 times lower than at in fresh and sea waters. These differences mainly originated from a lower spawning frequency and to a lesser extent from smaller spawn mass in hypersaline waters.

The results of E2 (acclimation over a few weeks) and E3 (lifetime acclimation), that were conducted in identical conditions, were mostly similar, except for egg WM and clutch size, which were significantly lower during E3, most probably because of the smaller size of broodfish during this experiment. Egg mass frequently increases with fish size in female S. melanotheron $<100-200 \mathrm{~g}$ whereas it varies very little in larger fish (von Kraft and Peters 1963; Legendre and Ecoutin 1996) and it is well known that absolute fecundity increases with increasing fish size. When the reproductive investment was equated to the body weight of females, the values obtained at a particular salinity in E2 and E3 were much closer (Figs. 1g and $1 \mathrm{~h}$ ). This supports the view that the use of broodfish of different sizes in the present series of experiments was no obstacle for comparing their reproductive investment as a function of the duration of the acclimation period.

The mean spawning frequencies observed during E1-E3 fall within the range already reported for $S$. melanotheron in captivity. Here the highest spawning frequency was one spawn per female every 20 days (E1, full strength sea salintiy, Table 2). Legendre and Trébaol (1996) found that the interval between consecutive spawning events for a particular female in brackish water could be as short as 10 days. On the other hand, Gilles et al. (2004) reported that captive females of $S$. $m$. heudelotii at salinities of 0 and 35 spawned on average every 

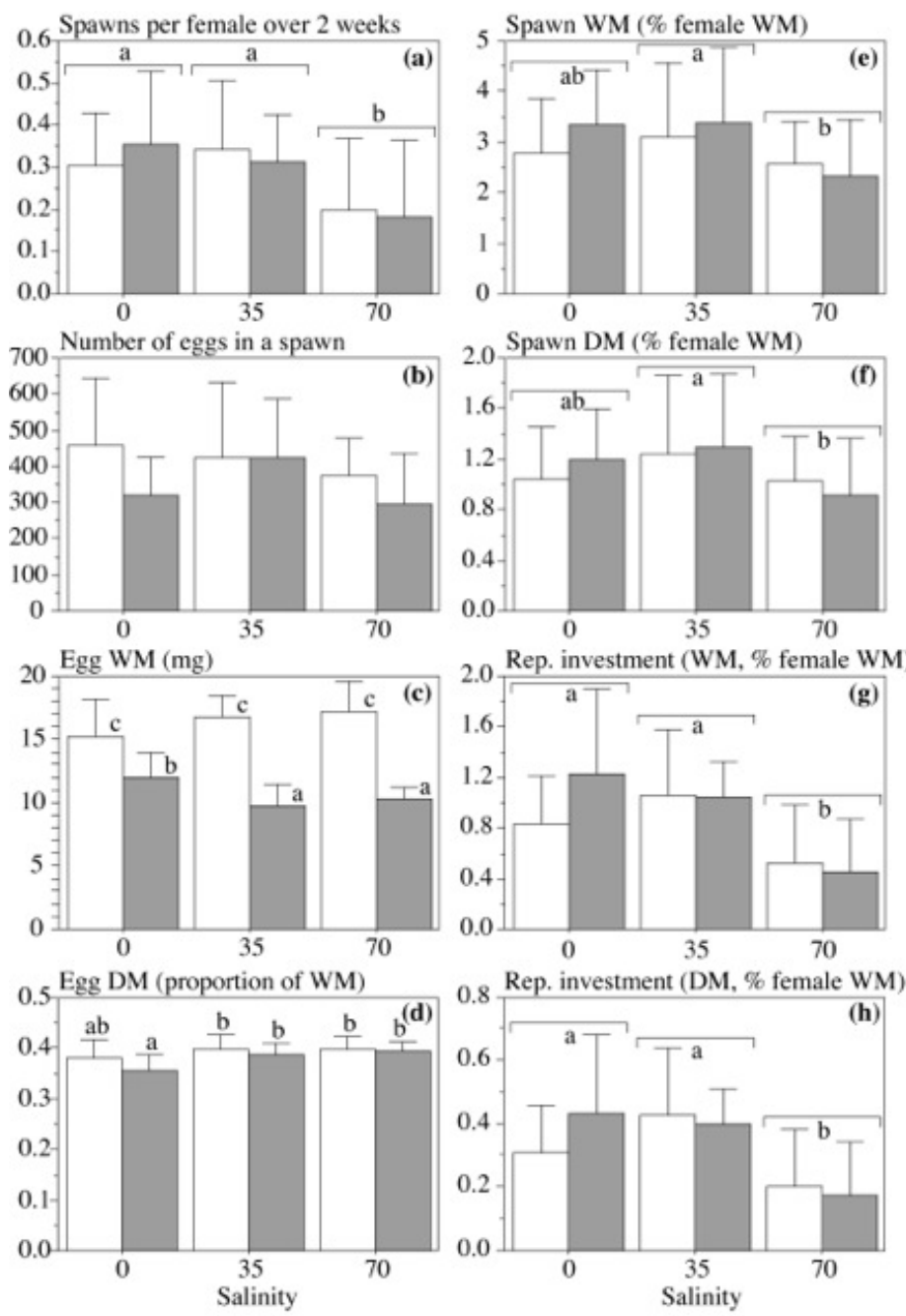

Fig. 1. Spawning frequency, characteristics of spawns and reproductive investment (over 2 weeks) of Saratherodon m. heudelotii during experiments E2 (open bars) and E3 (closed bars) (18 weeks each). WM is the wet mass and DM is the dry mass. Bars and whiskers are means \pm SD. Bars that do not share a lowercase letter in common differ at $p<0.05$ (Scheffe post-hoc tests).

13 weeks, i.e. about twice less frequently than here during E2 and E3. Likewise, the clutch size during E1 (620-630 eggs at $0-35)$ fell slightly below the values reported by Legendre and Trébaol (1996) for $S$. melanotheron of similar sizes in brackish water, but clutches of 300-500 eggs, as observed during E2 and E3, are frequent as well among captive fish at salinities from 0 to 35 (Cissé 1988; Gilles et al. 2004).

The higher spawning frequency and larger clutch size during E1 in comparison to E2-E3 could result from several differences in conditions of fish maintenance. First, the feed during E1 had higher protein and lipid contents. By analogy with the situation reported in some other cichlid species, fish receiving higher feeding levels or fed with higher protein or energy contents may display a higher spawning frequency or clutch size (Townshend and Wootton 1984; Santiago et al. 1985). However this trend is not systematic. Mironova (1978) reported a higher egg production in females of $O$. mossambicus experiencing a food shortage. On the other hand, Coward and Bromage (1999) observed no effect of food restriction on the reproductive characteristics of the redbelly tilapia Tilapia zillii (Gervais 1848). Likewise, Cissé (1988) found no significant differences between the spawning frequencies or clutch sizes in $S$. melanotheron fed different protein levels (20-50\%). The second factor that could account for the observed differences between E1 and E2-E3 refers to water temperature $\left(26.5^{\circ} \mathrm{C}\right.$ vs. $28.2^{\circ} \mathrm{C}$, respectively). Fish metabolism increases with water temperature (Jobling 1994). When fish are fed submaximal food rations, as was the case in the three experiments here, the scope for activity (energy available for activity, somatic or gonadal growth) decreases under warmer temperatures, and this may contribute to make the reproductive investment during E2 and E3 lower than during E1.

Whether the investment into reproduction was high (E1) or low (E2 and E3), fish at salinity 70 consistently spawned less frequently than those at salinities from 0 to 35 . The cost for osmoregulation increases when a fish is reared outside its preferred salinity range (for $S$. m. heudelotii, see Ouattara et al. 2009) and it results in slower growth or lower investment into gonads (Nile tilapia Oreochromis niloticus, Linnaeus 1758; Likongwe et al. 1996). There can be another reason why spawning frequency at a salinity of 70 was lower than at lower salinities. In contrast to the situations in fresh and 
Table 4. Results without any correction of the number of eggs in a spawn for mortality during egg incubation, as a function of ambient salinity $(0,35,70)$ and acclimation process (see Table 1 and Methods). Values are means \pm SD, WM: wet mass, DM: dry mass. The reproductive investment is calculated over two weeks; $p$-values for the effect of salinity that are indicated as ${ }^{* *},{ }^{*}$ and NS stand for $p<0.01, p<0.05$ and $p \geq 0.05$, respectively.

\begin{tabular}{lccccc}
\hline \multirow{2}{*}{ Experiment and salinity } & $\begin{array}{c}\text { Number of } \\
\text { eggs in a } \\
\text { spawn }\end{array}$ & $\begin{array}{c}\text { Spawn } \\
\text { WM }\end{array}$ & $\begin{array}{c}\text { Spawn } \\
\text { DM }\end{array}$ & $\begin{array}{c}\text { Rep. Invest. } \\
\text { WM }\end{array}$ & $\begin{array}{c}\text { Rep. Invest. } \\
\text { DM }\end{array}$ \\
\cline { 3 - 6 } & & \multicolumn{4}{c}{ \% female WM $)$} \\
\hline E1 0 & $544 \pm 164$ & $3.22 \pm 1.05$ & $1.30 \pm 0.43$ & $1.93 \pm 0.50$ & $0.78 \pm 0.20$ \\
35 & $623 \pm 221$ & $3.60 \pm 0.95$ & $1.44 \pm 0.38$ & $2.47 \pm 0.93$ & $1.03 \pm 0.41$ \\
70 & $341 \pm 179$ & $2.05 \pm 1.56$ & $0.76 \pm 0.60$ & $0.60 \pm 0.43$ & $0.23 \pm 0.17$ \\
ANOVA $-d f$ & 54 & 54 & 54 & 14 & 14 \\
$F$ and $p$ Salinity & $4.61^{*}$ & $3.75^{*}$ & $3.62^{*}$ & $6.577^{* *}$ & $6.91^{* *}$ \\
\hline E2 0 & $404 \pm 179$ & $2.47 \pm 1.04$ & $0.93 \pm 0.38$ & $0.74 \pm 0.37$ & $0.28 \pm 0.15$ \\
35 & $364 \pm 201$ & $2.75 \pm 1.49$ & $1.10 \pm 0.63$ & $0.99 \pm 0.45$ & $0.37 \pm 0.18$ \\
70 & $374 \pm 103$ & $2.57 \pm 0.83$ & $1.02 \pm 0.35$ & $0.52 \pm 0.46$ & $0.21 \pm 0.18$ \\
E3 0 & $294 \pm 104$ & $3.28 \pm 1.12$ & $1.17 \pm 0.42$ & $1.20 \pm 0.70$ & $0.43 \pm 0.25$ \\
35 & $348 \pm 150$ & $2.89 \pm 1.30$ & $1.11 \pm 0.51$ & $0.90 \pm 0.31$ & $0.35 \pm 0.12$ \\
70 & $296 \pm 140$ & $2.32 \pm 1.12$ & $0.91 \pm 0.45$ & $0.45 \pm 0.42$ & $0.18 \pm 0.17$ \\
Two-way ANOVA $-d f$ & 176 & 176 & 176 & 53 & 53 \\
$F$ and $p$ Salinity & $0.81 \mathrm{NS}$ & $1.30 \mathrm{NS}$ & $1.56 \mathrm{NS}$ & $5.87 * *$ & $7.70 * *$ \\
$F$ and $p$ Experiment & $6.97^{* *}$ & $1.11 \mathrm{NS}$ & $1.21 \mathrm{NS}$ & $1.49 \mathrm{NS}$ & $0.21 \mathrm{NS}$ \\
$F$ and $p$ Interaction & $1.41 \mathrm{NS}$ & $1.93 \mathrm{NS}$ & $1.87 \mathrm{NS}$ & $2.24 \mathrm{NS}$ & $0.99 \mathrm{NS}$ \\
\hline
\end{tabular}

marine waters, where offsprings were collected at all developmental stages, all spawns in hypersaline waters during E2 and E3 were collected at early developmental stages (before retinal pigmentation, Table 1). This is no indication that embryonic development halted at this stage in hypersaline waters, as spawns at more advanced stages were collected during E1 and spawns from E2 at salintity of 70 were used to produce viable offsprings for E3. Yet, it is likely that some mortality took place during mouthbrooding in hypersaline waters, but in view of the variation of clutch sizes in progenies of different ages, mortality rates in fresh and marine waters were similar (Table 1). Nevertheless, the impact of salinity on embryo survival in $S$. $m$. heudelotii should be further evaluated in the course of dedicated experiments with eggs incubated in controlled conditions (e.g., McDonald incubators). Instead of reflecting total embryo mortality, the absence of spawns at advanced developmental stages during E2 and E3 at a salinity of 70 most probably indicates that broodfish did not spawn during the first 2-3 days following weekly examination, possibly because they were more sensitive to handling than fish maintained at lower salinities. Whatever the exact reason for such delayed spawning, it might account at least partly for the overall lower reproductive investment in hypersaline waters during E2 and E3. Here, the broodfish under study came from a freshwater strain. It would be worth carrying out similar experiments for estimating the effect of salinity on reproductive performance with fish from other populations of $S$. m. heudelotii originating from saline or hypersaline environments.

The results of the present study echo to the current knowledge on the ecology of $S$. melanotheron. The finding that the reproductive investment of broodfish was similar in fresh and marine waters is not surprising in regards to the euryhaline nature of this species. By contrast, the present study provides evidence that the small size of broodfish found at very high salinities in the Saloum reverse estuary (Guèye et al. 2012) is not due to a physiological incapacity of larger individuals to reproduce in hypersaline waters. Indeed, Guèye et al. (2012) found no broodfish over $140 \mathrm{~g}$ in this ecosystem, whereas here broodfish $>250 \mathrm{~g}$ spawned consistently at a salinity of 70 in experimental conditions. This comparison further supports the view that the absence of large broodfish of $S$. m. heudelotii in the hypersaline areas of the Saloum reverse estuary is presumably not a direct consequence of water salinity, but rather originates from other causes such as oligotrophic environment, predation of large individuals by birds, or low oxygen. Low oxygen levels in the subsahelian Sine Salum can also be one of the reasons behind the smaller size of $S . m$. heudelotii parents and eggs in this environment. The duration of egg incubation is proportional to egg diameter and the oxygen demand of a particular egg increases during the ontogeny. Effects of oxygen restriction can proportionally be higher in mouthbrooders, which is energy demanding for the parent (Reardon and Chapman 2008). In hypoxic waters, the production of large eggs can thus be detrimental to the parent's fitness, and this may cause females to produce smaller eggs (e.g., Pseudocrenilabrus multicolor victoriae, Reardon and Chapman 2012). In the present study, egg size did not vary substantially between ambient salinities, in spite of the expectedly higher oxygen demand in hypersaline waters, but the oxygen level was maintained near saturation in all experimental situations.

In a broader context, the finding that freshwater fish acclimated to an hypersaline environment (salinity of 70) over a few weeks (E1 and E2) could reproduce as efficiently as fish born and maintained in such hypersaline water (E3), suggests that the environmental transition from a natural estuarine system to a hypersaline situation, as a result of drought, would be no major obstacle to the reproduction of $S$. $m$. heudelotii. This view is further supported by the fact that the fish under investigation 
here belong to a freshwater strain. This experimental evidence adds to previous findings that individuals of $S$. $m$. heudelotii can rapidly acclimate to hypersaline conditions, as exemplified by the changes in their gill structure and associated osmoregulatory capacities (Ouattara et al. 2009), and by the modification of osmolality requirements for the activation of sperm (Legendre et al. 2008 and unpubl. data). Similar rapid acclimation to different environments has been observed in other cichlids. Duponchelle and Legendre (2001) reported that it took no more than one or two reproductive cycles for female $O$. niloticus to change their fecundity and egg size in response to modifications of spatial structure in experimental environments. From a physiological perspective, it is known that fish acclimation to salinity can be mediated by the intracellular accumulation of small organic molecules named osmolytes (e.g. myo-inositol), which enable them to offset hyperosmotic challenge (Yancey et al. 1982). Gardell et al. (2013) found that the accumulation of myo-inositol in fish brain can be very rapid in a euryhaline species, the Mozambique tilapia, which could cope with daily elevations of salinity of 7.5 from 0 to 90 in experimental environments. Such very rapid acclimation dynamics in a euryhaline species might account for why there were little differences in the present study between fish acclimated to hypersaline waters within a few weeks and those born in hypersaline waters. Nevertheless, this biosynthetic pathway is energy demanding, and contributes to increasing the cost of living at elevated salinity, thereby accounting for the overall lower reproductive investment in hypersaline waters.

In conclusion, the present study further highlights and documents the remarkable capacities of $S$. $m$. heudelotii to thrive in a broad range of salinities, even after rapid salinity transitions. The finding that the reproductive performance of fish acclimated from fresh water to hypersaline water in a few weeks can perform as well as fish born and maintained on the long term at these salinities opens a broad range of perspectives in terms of fish and gamete physiology, which are still to be addressed. To be further comprehensive, future studies in controlled conditions should also consider the effect of salinity on the survival of eggs and free embryos, and ideally test these effects for populations of $S$. m. heudelotii originating from environments with contrasting salinities.

Acknowledgements. Moussa Guèye benefited from an IRD (Institut de Recherche pour le Développement) grant for his Ph.D. thesis. This is a publication ISEM-2014-212. Etienne Baras is a honorary research associate of the Belgian National Foundation for Scientific Research. This study was supported by an INSU-EC2CO Grant (IPREP, 20102012).

\section{References}

Abramoff M.D., Magalhaes P.J., Ram S.J., 2004, Image Processing with ImageJ. Biophotonics Int. 11, 36-42.

Albaret J.-J., 1987, Les peuplements de poissons de la Casamance (Sénégal) en période de sécheresse. Rev. Hydrobiol. Trop. 20, 291-310.

Alcaraz C., García-Berthou E., 2007, Life history variation of invasive mosquitofish (Gambusia holbrooki) along a salinity gradient. Biol. Conserv. 139, 83-92.
Akinrotimi O.A, Ansa E.J., Owhonda K.N., Edun O.M., Onunkwo D.N., Opara J.Y., Anyanwu P.E., Amachree D., 2007, Variations in oxygen carrying capacity of Sarotherodon melanotheron blood in different acclimation media. J. Anim. Vet. Adv. 6, 932-937.

Aronson L.R., 1949, An analysis of reproductive behaviour in the mouthbreeding cichlid fish, Tilapia macrocephala (Bleeker). Zoologica 34, 133-158.

Avarre J.-C., Dugué R., Alonso P., Diombokho A., Joffrois C., Faivre N., Cochet C., Durand J.-D., 2014, Analysis of the black-chinned tilapia Sarotherodon melanotheron heudelotii reproducing under a wide range of salinities: from RNA-seq to candidate genes. Mol. Ecol. Resour. 14, 139-149.

Brown-Peterson N., Peterson M.S., 1990, Comparative life history of female mosquitofish, Gambusia affinis, in tidal freshwater and oligohaline habitats. Environ. Biol. Fishes 27, 33-41.

Chervinsky J., 1982, Environmental physiology of tilapias. In: Pullin R.S.V., Lowe-McConnell R.H. (Eds.), The Biology and Culture of Tilapias. Manila, ICLARM, pp. 119-129.

Cissé A., 1988, Effects of varying protein levels on spawning frequency and growth of Sarotherodon melanotheron. In: Pullin R.S.V., Bhukaswan T., Tonguthai K., Maclean J.L. (Eds.), The Second Symposium on Tilapia in Aquaculture. Manila, ICLARM Conf. Proc. 15, pp. 329-333.

Coward K., Bromage N.R., 1999, Spawning frequency, egg size and ovarian histology in groups of Tilapia zillii maintained upon two distinct food ration sizes from first-feeding to sexual maturity. Aquat. Living. Resour. 12, 11-22.

Crear D., 1980, Observations on the reproductive state of milkfish populations (Chanos chanos) from hypersaline ponds on Christmas Island (Pacific Ocean). Proc. World Mar. Soc. 11, 548556.

Diouf K., Panfili J., Labonne M., Aliaume C., Tomas J., Do Chi T., 2006, Effects of salinity on strontium:calcium ratios in the otoliths of the West African black-chinned tilapia Sarotherodon melanotheron in a hypersaline estuary. Environ. Biol. Fishes 77, 9-20.

Duponchelle F., Legendre M., 2001, Rapid phenotypic changes of reproductive traits in response to modification of spatial structure in Nile tilapia, Oreochromis niloticus. Aquat. Living Resour. 14, $145-152$.

Fridman S., Bron J.E., Rana K.J., 2012, Ontogenic changes in the osmoregulatory capacity of the Nile tilapia Oreochromis niloticus and implications for aquaculture. Aquaculture 356, 243-249.

Gardell A.M., Yang J., Sacchi R., Fangue N.A., Hammock B.D., Kültz D., 2013, Tilapia (Oreochromis mossambicus) brain cells respond to hyperosmotic challenge by inducing myo-inositol biosynthesis. J. Exp. Biol. 216, 4615-4625.

Gilles S., Zamora L., Amiel C., Nuñez-Rodriguez J., 2004, Comparative study of reproductive characteristics of the euryhaline tilapia, Sarotherodon melanotheron heudelotii in fresh and sea waters. J. Aquac. Trop. 19, 277-284.

Gilles S., Lacroix G., Corbin D., Ba N., Luna C.I., Nandjui J., Ouattara A., Ouedraogo O., Lazzaro X., 2008, Mutualism between euryhaline tilapia Sarotherodon melanotheron heudelotii and Chlorella sp. - Implications for nano-algal production in warmwater phytoplankton-based recirculating systems. Aquac. Eng. 39, 113-121. 
Gilles S., Fargier L., Lazzaro X., Baras E., De Wilde N., Drakides C., Amiel C., Rispal B., Blancheton J.-P., 2013, An integrated fishplankton aquaculture system in brackish water. Animal 7, 322 329.

Guèye M., Tine M., Kantoussan J., Ndiaye P., Thiaw O.T., Albaret J.-J., 2012, Comparative analysis of reproductive traits in blackchinned tilapia females from various coastal marine, estuarine and freshwater ecosystems. PLoS One 7(1), e29464.

Jobling M., 1994, Fish Bioenergetics. London, Chapman and Hall.

Keenleyside M.H.A. (Ed.), 1991, Cichlid Fishes. Behaviour, Ecology and Evolution. London, Chapman and Hall.

Legendre M., Cosson J., Alavi S.M.H., Linhart O., 2008, Activation of sperm motility in the euryhaline tilapia Sarotherodon melanotheron heudelotii (Dumeril, 1859) acclimatized to fresh, sea and hypersaline waters. Cybium 32, 181-182.

Legendre M., Ecoutin J.-M., 1989, Suitability of brackish water tilapia species from the Ivory Coast for lagoon aquaculture. I - Reproduction. Aquat. Living Resour. 2, 71-79.

Legendre M., Ecoutin J.-M., 1996, Aspects of the reproductive strategy of Sarotherodon melanotheron: comparison between a natural population (Ebrie Lagoon, Côte d'Ivoire) and different cultured populations. In: Pullin R.S.V., Lazard J., Legendre M., Amon Kothias J.-B., Pauly D. (Eds.), The Third Symposium on Tilapia in Aquaculture. Manila, ICLARM Conf. Proc. 41, pp. 326-338.

Legendre M., Trébaol L., 1996, Mouthbrooding efficiency and spawning frequency of Sarotherodon melanotheron (Rüppel, 1852) in culture environments (Ebrié Lagoon, Côte d'Ivoire). In: Pullin R.S.V., Lazard J., Legendre M., Amon Kothias J.-B., Pauly D. (Eds.), The Third Symposium on Tilapia in Aquaculture. Manila, ICLARM Conf. Proc. 41, pp. 339-348.

Lévêque C., 1999, Les peuplements des lacs peu profonds. In: Lévêque C., Paugy D. (Eds.), Les poissons des eaux continentales africaines : diversité, écologie, utilisation par l'homme. Montpellier, IRD, pp. 311-323.

Likongwe J.S., Stecko T.D., Stauffer J.R.Jr., Carline R.F., 1996, Combined effects of water temperature and salinity on growth and feed utilization of juvenile Nile tilapia Oreochromis niloticus (Linnaeus). Aquaculture 146, 37-46.

Lorin-Nebel C., Avarre J.-C., Faivre N., Wallon S., Charmantier G., Durand J.-D., 2012, Osmoregulatory strategies in natural populations of the black-chinned tilapia Sarotherodon melanotheron exposed to extreme salinities in West African estuaries. J. Comp. Physiol. B 182, 771-780.

Mironova N.V., 1977, Energy expenditure on egg production in young Tilapia mossambica and the influence of maintenance conditions on their reproductive intensity. J. Ichthyol. 17, 627-633.

Naddafi R., Abdoli A., Kiabi B.H., Amiri B.M., Karami M., 2005, Age, growth and reproduction of the Caspian roach (Rutilus rutilus caspicus) in the Anzali and Gomishan wetlands, North Iran. J. Appl. Ichthyol. 21, 492-497.

Ndiaye A., 2012, Réponses du tilapia Sarotherodon melanotheron aux stress multiples (salinité et contaminants chimiques) : approche multi-paramétrique. Université Montpellier 2, Thèse de Doctorat.

Nordlie F.G., Walsh S.J., Haney D.C., Nordlie T.F., 1991, The influence of ambient salinity on routine metabolism in the teleost Cyprinodon variegatus Lacepède. J. Fish Biol. 38, 115-122.
Ouattara N., Bodinier C., Nègre-Sadargues G., D'Cotta H., Messad S., Charmantier G., Panfili J., Baroiller J.-F., 2009, Changes in gill ionocyte morphology and function following transfer from fresh to hypersaline waters in the tilapia Sarotherodon melanotheron. Aquaculture 290, 155-164.

Panfili J., Mbow A., Durand J.-D., Diop K., Diouf K., Thior D., Ndiaye P., Laë R., 2004, Influence of salinity on the life-history traits of the West African blackchinned tilapia (Sarotherodon melanotheron): comparison between the Gambia and Saloum estuaries. Aquat. Living Resour. 17, 65-74.

Panfili J., Thior D., Ecoutin J.-M., Ndiaye P., Albaret J.-J., 2006, Influence of salinity on the size at maturity for fish species reproducing in contrasting West African estuaries. J. Fish Biol. 69, 95-113.

Papah M.B., Kisia S.M., Ojoo R.O., Makanya A.N., Wood C.M., Kavembe G.D., Maina J.N., Johannsson O.E., Bergman H.L., Laurent P., Chevalier C., Bianchini A., Bianchini L.F., Onyango D.W., 2013, Morphological evaluation of spermatogenesis in Lake Magadi tilapia (Alcolapia grahami): a fish living on the edge. Tissue Cell 45, 371-382.

Plaut I., 2000, Resting metabolic rate, critical swimming speed, and routine activity of the euryhaline cyprinodontid, Aphanius dispar, acclimated to a wide range of salinities. Physiol. Biochem. Zool. 73, 590-596.

Rao T.R., 1975, Salinity tolerance of laboratory-reared larvae of the California killifish, Fundulus parvipinnis Girard. J. Fish Biol. 7, 783-790.

Reardon E.E., Chapman L.J., 2008, Reproductive seasonality in a swamp-locked African cichlid. Ecol. Freshw. Fish 17, 20-29.

Reardon E.E., Chapman L.J., 2012, Fish embryo and juvenile size under hypoxia in the mouth-brooding African cichlid Pseudocrenilabrus multicolor. Curr. Zool. 58, 401-412.

Riou V., Ndiaye A., Budzinski H., Dugué R., Le Ménach K., Combes Y., Bossus M., Durand J.-D., Charmantier G., Lorin-Nebel C., 2012, Osmoregulatory strategies in natural populations of the black-chinned tilapia Sarotherodon melanotheron exposed to extreme salinities in West African estuaries. Comp. Biochem. Physiol. C 156, 7-16.

Russell D.J., Thuesen P.A., Thomson F.E., 2012. Reproductive strategies of two invasive tilapia species Oreochromis mossambicus and Tilapia mariae in northern Australia. J. Fish Biol. 80, 2176-2197.

Santiago C.B., Aldaba M.B., Abuan E.F., Laron M.A., 1985, The effects of artificial diets on fry production and growth of Oreochromis niloticus breeders. Aquaculture 47, 193-203.

Shaw E.S., Aronson L.R., 1954, Oral incubation in Tilapia macrocephala. Am. Mus. Nat. Hist. 103, 380-415.

Schofield P.J., Peterson M.S., Lowe M.R., Brown-Peterson N.J., Slack W.T., 2011, Survival, growth and reproduction of nonindigenous Nile tilapia, Oreochromis niloticus (Linnaeus 1758). I. Physiological capabilities in various temperatures and salinities. Mar. Freshw. Res. 62, 439-449.

Simier M., Blanc L., Aliaume C., Diouf P.S., Albaret J.-J., 2004, Spatial and temporal structure of fish assemblages in an "inverse estuary", the Sine Saloum system (Senegal). Estuar. Coast. Shelf Sci. 59, 69-86.

Tine M., Bonhomme F., McKenzie D.J., Durand J.-D., 2010, Differential expression of the heat shock protein Hsp70 in natural populations of the tilapia, Sarotherodon melanotheron, acclimatised to a range of environmental salinities. BMC Ecol. 10, 11. 
Tine M., de Lorgeril J., D’Cotta H., Pepey E., Bonhomme F., Baroiller J.-F., Durand J.-D., 2008, Transcriptional responses of the blackchinned tilapia Sarotherodon melanotheron to salinity extremes. Mar. Genom. 1, 37-46.

Townshend T.J., Wootton R.J., 1984, Effects of food supply on the reproduction of the convict cichlid, Cichlasoma nigrofasciatum. J Fish Biol. 24, 91-104.

Trewavas E., 1983, Tilapine fishes of the genera Sarotherodon, Oreochromis and Danakilia. London, British Museum.

von Kraft A., Peters H.M., 1963, Fecundity, egg weight and oocyte development in tilapias (Cichlidae, Teleostei). Z. Zellforsch. Mikrosk. Anat. 61, 434-485 (in German). Translated in English and edited by Pauly D., 1983. Manila: ICLARM Translations 2.

Watanabe W.O., Burnett K.M., Olla B.L., Wicklund R.I., 1989, The effects of salinity on reproductive performance of Florida red tilapia. J. World Aquac. Soc. 20, 223-229.
Whitfield A.K., Taylor R.H., Fox C., Cyrus D.P., 2006, Fishes and salinities in the St Lucia estuarine system - a review. Rev. Fish Biol. Fish. 16, 1-20.

Wood C.M., Wilson P., Bergman H.L., Bergman A.N., Laurent P., Otiang'a-Owiti G., Walsh P.J., 2002, Obligatory urea production and the cost of living in the Magadi tilapia revealed by acclimation to reduced salinity and alkalinity. Physiol. Biochem. Zool. $75,111-122$.

Wood C.M., Bergman H.L., Bianchini A., Laurent P., Maina J., Johannsson O.E., Bianchini L.F., Chevalier C., Kavembe G.D., Papah M.B., Ojoo R.O., 2012. Transepithelial potential in the Magadi tilapia, a fish living in extreme alkalinity. J. Comp. Physiol. B 182, 247-258.

Yancey P.H., Clark M.E., Hand S.C., Bowlus R.D., Somero G.N., 1982, Living with water stress: evolution of osmolyte systems. Science 217, 1214-1222. 